\title{
Groundwater Pollution and Remediation
}

\author{
Abel 0. Talabi*, Tosin J. Kayode \\ Department of Geology, Ekiti State University, Ado-Ekiti, Nigeria \\ Email: *abel.talabi@eksu.edu.ng
}

How to cite this paper: Talabi, A.O. and Kayode, T.J. (2019) Groundwater Pollution and Remediation. Journal of Water Resource and Protection, 11, 1-19. https://doi.org/10.4236/jwarp.2019.111001

Received: November 23, 2018

Accepted: January 11, 2019

Published: January 14, 2019

Copyright (c) 2019 by author(s) and Scientific Research Publishing Inc. This work is licensed under the Creative Commons Attribution International License (CC BY 4.0).

http://creativecommons.org/licenses/by/4.0/ (c) (i) Open Access

\begin{abstract}
Groundwater pollution is imminent in most developing countries as a result of increased anthropogenic activities apart from possible natural pollutants. This study reviewed groundwater pollution and discussed possible remediation measures. Sources of pollution can be categorized into two major types: point source pollution and non-point source pollution. Point source pollution (e.g. municipal sewage treatment plant and industrial plant, intense evaporation in shallow aquifers, degradation of water sources in areas located in geothermal/volcanic fields, and rock oxidation) is a single identify localized source while non-point source pollution (diffuse sources such as human land use, land use changes, chemical reactions of elements in the air or in the water and pollutes runoff from agricultural areas draining into a river) is characterized by multiple discharge point. Point source is relatively easy to identify, quantify and control. On the other hand, non-point source is difficult to monitor and control because the pollution cannot be traced to a single point of discharge. Pollution occurrence depends on the level of contaminant transported. Contaminants can be transported through filtration, sorption, chemical processes, microbiological decomposition and dilution. Groundwater pollution may cause ecosystem imbalance apart from severe sickness which may lead to death. Prevention of groundwater pollution is more appropriate than remediation. Such preventive measures include proper waste disposal, monitoring of hazardous materials, conducting environmental audit periodically and intensifying health education while remediation includes stream stripping, oxygen sparging, bioremediation, chemical oxidation and thermal treatment. This study revealed two main sources (point source and non-point source) of pollution with non-point pollution more difficult to remediate due to extent of spread. In addition, most pollution of groundwater is anthropocentric and can be prevented through intensive health education.
\end{abstract}

\section{Keywords}

Groundwater, Pollutants, Anthropogenic, Remediation, Health Education 


\section{Introduction}

Water covers over $70 \%$ of the earth surface and is undoubtedly the most precious natural resource that exists on the earth. Without the seemingly invaluable compound comprised of hydrogen and oxygen, life on the earth would be non-existent. Water is a key ingredient surporting food production, sanitation and rural livelihoods, as well as ensuring continuity and functioning of ecosystem. It dictates the pace of settlement and agricultural and industrial development of any society and even in recent time, establishment of any human settlement is usually centered on available source of water supply and in modern time, issue of water has equally taken prominences in global matters [1].

The distribution of world's water indicates that only $2.5 \%$ and $97.5 \%$ constitute fresh water and saline water respectively. $2.5 \%$ of the world's freshwater, surface water and groundwater have $0.4 \%$ and $30.1 \%$ representations respectively [2]. Most of the freshwater is locked up in ice caps at the Polar region. The distribution of world's water skewed towards saline water dominance which placed restriction on its availability for humans, agriculture and industrial uses. Furthermore, more exacerbating was the rapid rise in world's population that rose to 7.6 billion [3]. At the beginning of the nineteenth century, the total world population crossed the threshold of 1 billion people for the first time in the history of the Homo sapiens. Since then, growth rates have been increasing exponentially, reaching staggeringly high peaks in the 20th century and slowing down a bit thereafter. The total world population reached 7 billion just after 2010 and is expected to count 9 billion by 2045 [4]. This population growth revealed unprecedented increase in the last 200 years as it took over 200,000 years of human history for the world's population to reach 1 billion and only 200 years to reach 7 billion. The increase in population and its attendant problems (depletion of natural resources, environmental degradation, conflicts and wars, lack of adequate food, water, shelter, education and employment, high cost of living and increase in anthropogenic activities) have placed stress on the available global fresh water leading to water crisis in the world. The "looming water crisis" is becoming a major issue on the world agenda for the twenty-first century. The World Water Council presented the "World Water Vision" during the Second World Water Forum and Ministerial Conference at The Hague in March 2000 [5]. The Vision reported that 1.2 billion people or one fifth of the world population do not have access to safe drinking water, while half of the world population lack adequate sanitation. The Vision further states that rapidly growing cities, burgeoning industries and rapidly rising use of chemicals in agriculture have undermined the quality of many rivers, lakes, aquifers and also emphasized that the impacts of agriculture on water quality are less visible over time but at least as dangerous as industrial because many of the fertilizers, pesticides and herbicides used to improve agricultural productivity slowly accumulate in groundwater aquifers and natural ecosystems.

The term quality of groundwater refers to its physical, chemical, and biologi- 
cal characteristics as they relate to the intended use of water. Groundwater quality is threatened mainly by human activities, although harmful substances are sometimes introduced by natural processes. Sustainable groundwater management must be based not only on prevention of the over exploitation of groundwater resources but also on prevention of contamination because unlike treatment at the point of use, prevention protects all of the resource. However, economic activities (primary activities) which produce commodities (mining, agriculture) and secondary or industrial activities (energy production, manufacturing, building, etc.) in addition to services (including transport) and households activities result into generation of enormous waste products which threatens the environment and leads to increasing groundwater pollution [6] [7]. There are two main sources of groundwater pollution; point source and non-point source [8]. In principle, waste sites can be isolated from the environment. This, however, is not possible with diffuse sources of contamination which are either introduced into the air or subsequently rained out or are used in agriculture and partly infiltrate into the subsurface. These sources, together with mine tailings and accidental spills of hazardous substances represent major threats to groundwater quality.

Understanding the physical environment of groundwater is important in its pollution evaluation. Groundwater is the great "unseen" salient element of the hydrologic cycle. Because it is out of sight it is frequently out of mind [9]. The groundwater regime is a dynamic system in which water is continuously in motion. In a typical groundwater system this movement occurs through extensive heterogeneous material via an interconnected geological framework. A schematic representation of groundwater and its relationship to the rest of the hydrologic system is presented in Figure 1. Out of the water entering the ground reservoirs, some will rise in the form of springs or move downstream until it reaches a lake or the ocean where it is again evaporated. In the course of the various processes of infiltration and the contribution of river and drainage systems to the base-flow, natural water-rock interactions ensue apart from anthropogenic activities that can introduce pollutant into the groundwater system [10]. The focus of this study is on groundwater pollution with a view to detecting sources of pollution, its effects, indicators, solutions and the methods of preventing/remediating it.

\section{Groundwater Pollution}

Water is the most precious resource that humans utilize from nature. It is a life support system not only for humans but "is the living environment for a large proportion of earth's animals and plants" [11]. Groundwater is just a part of the larger water system. Both the quality and quantity of the groundwater resource are important at a global, national and local scale. In the Dictionary of Life Sciences, pollution is defined as: "the presence in the environment of significant amounts of unnatural substances or abnormally high concentrations of natural constituents at a level that causes undesirable effects, such as bronchial irritations, 


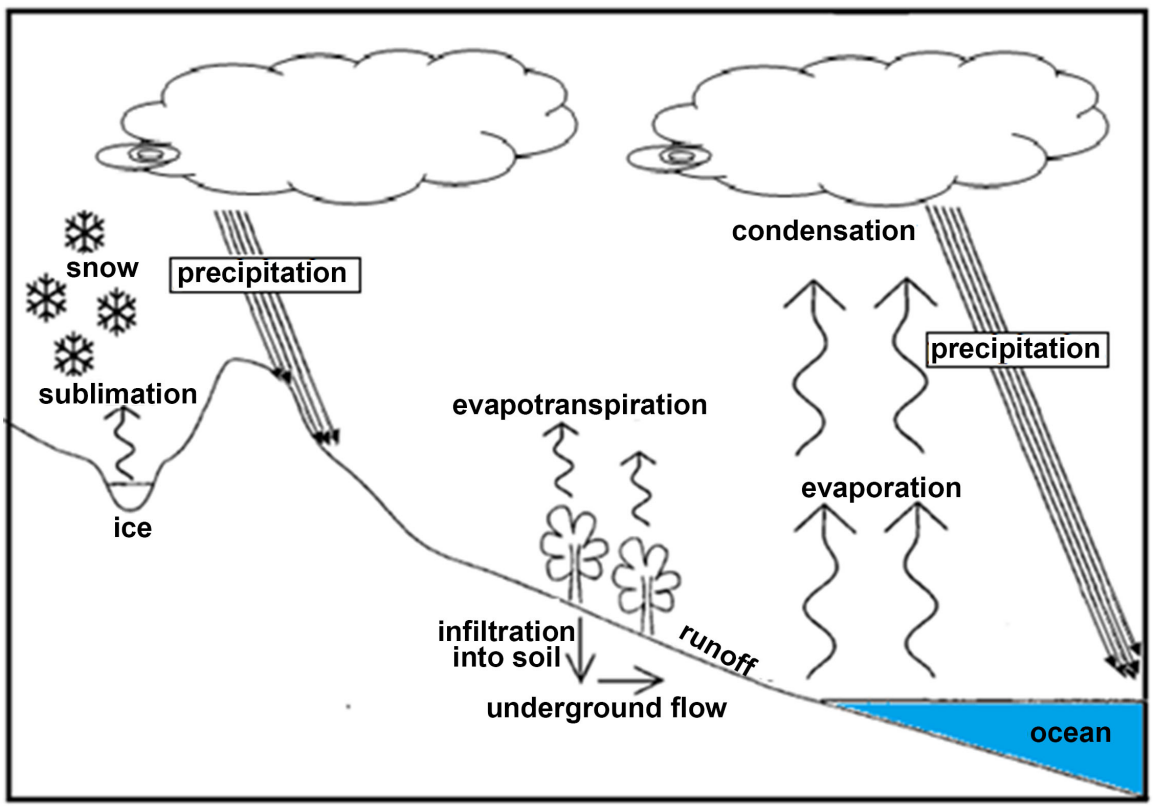

Figure 1. Schematic diagram illustrating the hydrologic cycle.

corrosion or ecological change". [12] stated that pollution occurs when "substances are added to the environment causing a detrimental alteration to its physical, chemical, biological or aesthetic characteristic". Pollutants in this context are either foreign substances or natural substances discharged in excessive amounts. Pollution can therefore, be seen as a consequence of human activity as well as a natural phenomenon. Groundwater pollution therefore is when foreign or natural substances are found in the underground water at levels that post threat to humans' and/or plants' health. Most definitions are anthropocentric and concerned mainly with the effects of the pollutants on man. This study also takes an anthropocentric viewpoint in that it is concerned with the causes/sources of potential pollution that are human induced, the effects/consequences of pollution on humans and management options will relate to human activity. Groundwater contamination is nearly always the result of human activity. In areas where population density is high and human use of the land is intensive, groundwater is especially vulnerable. Virtually any activity whereby chemicals or wastes may be released to the environment, either intentionally or accidentally, has the potential to pollute groundwater. When ground water becomes contaminated, it is difficult and expensive to clean up.

To begin to address pollution prevention or remediation, we must understand how surface water and groundwater interrelate. Groundwater and surface water are interconnected and can be fully understood and intelligently managed only when that fact is acknowledged. If there is a water supply well near a source of contamination, that well runs the risk of becoming contaminated (Figure 2). If there is a nearby river or stream, that water body may also become polluted by the groundwater. Depending on its physical, chemical, and biological properties, a contaminant that has been released into the environment may move within an 


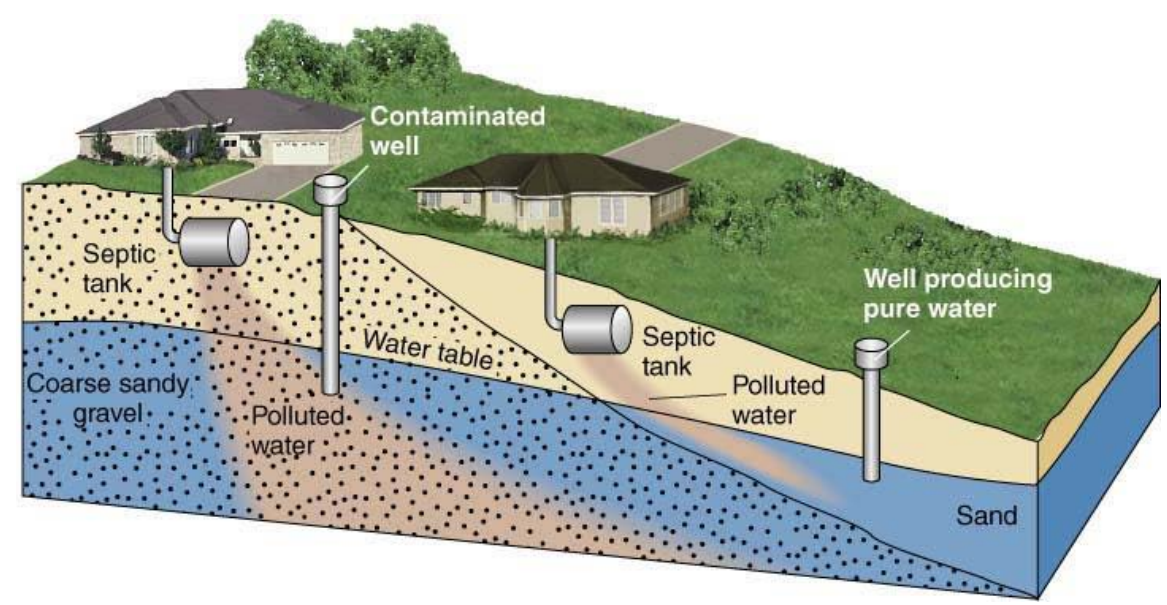

Figure 2. 3D groundwater contamination [13].

aquifer in the same manner that groundwater moves. Some contaminants do not always follow groundwater flow. It is possible to predict, to some degree, the transport within an aquifer of those substances that move along with groundwater flow.

For example, both water and certain contaminants flow in the direction of the topography from recharge areas to discharge areas. Soils that are porous and permeable tend to transmit water and certain types of contaminants with relative ease to an aquifer below. Just as groundwater generally moves slowly, so do contaminants in groundwater. Because of this slow movement, contaminants tend to remain concentrated in the form of a plume (Figure 3 ) that flows along the same path as the groundwater. The size and speed of the plume depend on the amount and type of contaminant, its solubility and density and the velocity of the surrounding groundwater.

Groundwater and contaminants can move rapidly through fractures in rocks. Fractured rock presents a unique problem in locating and controlling contaminants because the fractures are generally randomly spaced and do not follow the contours of the land surface or the hydraulic gradient. Contaminants can also move into the groundwater system through macropores-root systems, animal burrows, abandoned wells, and other systems of holes and cracks that supply pathways for contaminants. Some drinking water wells actually draw water from nearby streams, lakes or rivers. Contaminants present in these surface waters can contribute contamination to the ground water system. Some wells rely on artificial recharge to increase the amount of water infiltrating an aquifer, often using water from storm runoff, irrigation, industrial processes or treated sewage. In several cases, this practice has resulted in increased concentrations of nitrates, metals, microbes or synthetic chemicals in the water.

\section{Mechanisms of Groundwater Pollution}

The contaminant introduced into the soil-rock-groundwater system will spread within the system only if a transport mechanism is available, for example, a 


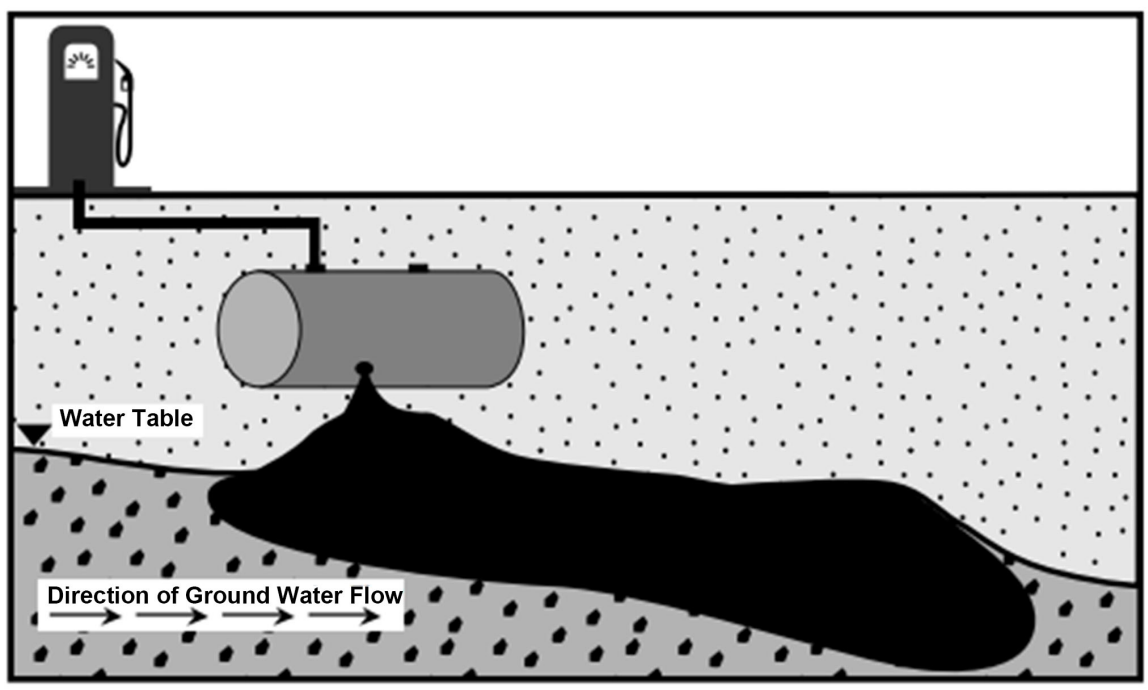

Figure 3. Contaminant plume [15].

flowing liquid. As soon as the contaminant reaches the subsurface water in the unsaturated or saturated zone, various processes (physical, geochemical and biochemical) determine its fate [14]. The physical processes include advection, dispersion, evaporation, filtration, and degassing while those of geochemical are acid-base reactions, adsorption-desorption, ion exchange, oxidation-reduction, precipitation-dissolution, retardation and complexation. The biochemical processes include amongst others transpiration, bacterial respiration, decay and cell synthesis (Figure 4). The movement of a chemical pollutant within an aquifer is described by the "transport equation" (Equation (1)):

$$
\frac{\partial C}{\partial t}-v\left(\frac{\partial C}{\partial t}\right)+D\left(\frac{\partial^{2} C}{\partial x^{2}}\right)-\frac{\partial q}{\partial t}
$$

where $C$ is the concentration of the contaminant, $t$ is time, $x$ is the distance in the flow path, $v$ is the average water flow velocity in the porous media, $D$ is the hydrodynamic dispersion coefficient and $q$ is a coefficient regarding to processes affecting the concentration.

This equation considers mass conservation over an elemental volume of the aquifer and it is also known as the advection-dispersion equation as these are the two main processes controlling solute transport in a porous media. It includes (from left to right) an advection term, a dispersion term and a source/sink term that describes different processes affecting the concentration. Thus this equation considers the multiple ways in which a contaminant could move within an aquifer. Overall, advection is by far more relevant for contaminant transport than diffusion in sedimentary aquifers, whereas diffusion is the most relevant process in aquitards (i.e., geological materials of low hydraulic conductivity).

\section{Pollution Classification}

Water resources pollution and the respective groundwater quality degradation are caused by various human activities which result in the change of water 


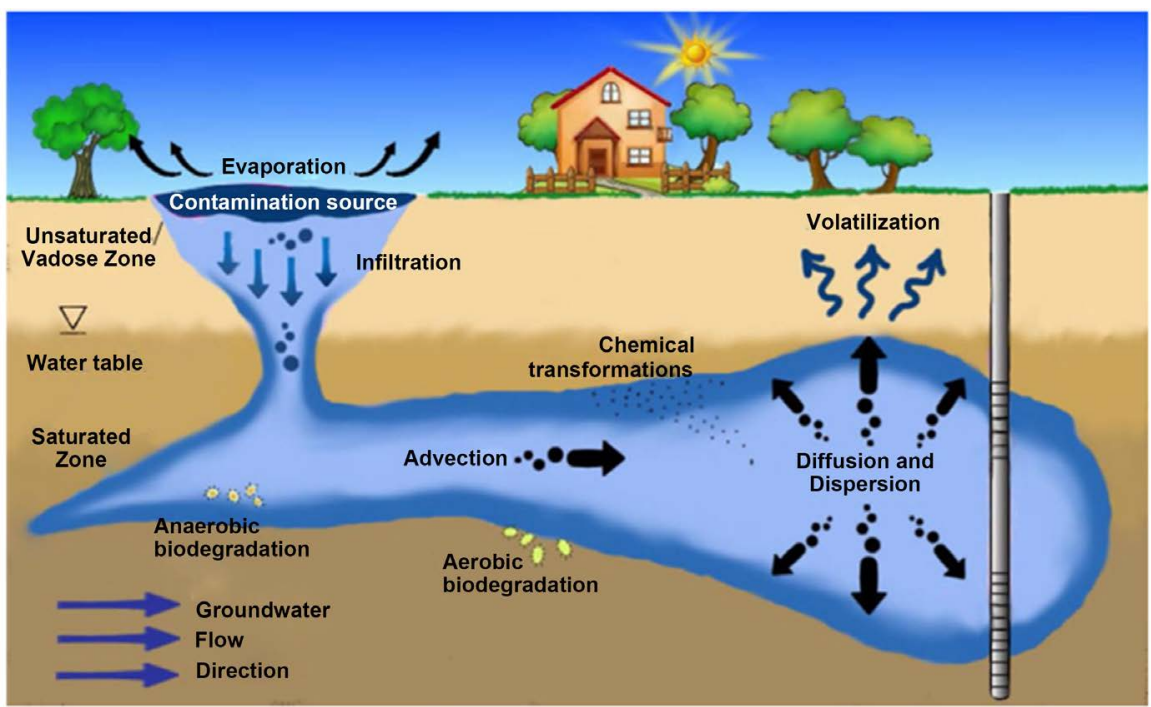

Figure 4. Main processes involved in contaminant transport in the aquifer [14].

physicochemical characteristics. Groundwater pollution sources can be classified based on different parameters (origin, geometry of the source and transmission rate).

Pollution sources as a result of origin could be natural or anthropogenic, geometry of the source could be point source (landfills, waste dumps, septic tanks, underground tanks), linear (roads) and diffused (nitro pollution, acid rain, uranium decay) while the transmission rate represents continuous and recurrent transmission of pollutant.

\subsection{Anthropogenic and Natural Pollution Sources}

The most common pollution sources are the anthropogenic ones. This category generally includes: disposal of wastewater and solid waste, disposal of industrial wastewater, use of fertilizers, pesticides and insecticides, disposal of by-products and waste from mining activities and nuclear energy waste. Anthropogenic sources can be caused by different activities such as over-pumping, unlimited use of fertilizers, mining activities, waste dumps, extended urban development, change of climatic conditions (microclimate), misuse of chemicals, disposal of organic and inorganic elements, heaps and sewage storage, river network interruption, mineral processing of radioactive minerals and cemeteries. Pollutants such as trace elements are concentrated in the discharge material/water from various anthropogenic activities and can be toxic and lethal to humans. Other contaminants that have been detected in groundwater and are related to human activities are hydrocarbons, halogens, biphenyls and biological contamination (bacteria; viruses; parasites). Groundwater can also be polluted through natural causes, i.e., the results of cycles or of natural phenomena. This category includes the following sources: easy to dissolve rocks (gypsum, mineral salt etc.), intense evaporation especially in shallow aquifers which causes elevation of groundwater and salt deposition, degradation of water sources in areas located in geother- 
$\mathrm{mal} /$ volcanic fields, rock oxidation, seawater intrusion, decay of radioisotopes from uranium-rich bedrock, and chemical reactions of elements in the air or in the water.

\subsection{Point and Non-Point Pollution Sources}

Possible water pollutant sources are numerous and can also be classified into point sources and diffuse pollution sources. Pollution of surface waters is directly related with groundwater pollution. Thus, pollution of surface water usually results in respective groundwater pollution. Groundwater pollution sources are summarized in Table 1 and Figure 5. Major point sources include municipal and industrial wastewater treatment plant effluents, which can be located in urban, industrial or agricultural regions [16] [17]. It is not unusual that wastewater treatment plants, combined sewage-storm water overflows treatment plants or improper treatment of hospital effluents does not provide a final effluent of appropriate quality. Specific organic micro pollutants might end up in this way in surface and groundwater [18]. Other point sources of groundwater pollution are industrial activities such as food processing, mining activities, manufacturing plants, livestock farms and landfill sites.

Domestic wastewater from residences, institutions or other facilities such as confectioneries, restaurants, laundries etc. is a major pollution point source. It mainly consists of water containing organic and inorganic compounds, as well as bacteria and viruses. Organic matter in domestic wastewater can be faeces, urine, paper, soaps, detergents, food residuals, fats and oils while inorganic materials include ammonia, ammonium salts, clay, phosphorus etc. [18]. Wastewater disposal creates pollution problems to the environment such as eutrophication, groundwater pollution and limitation of the natural self-purification capacity of water.

Industrial wastewater refers to wastewater from various industries, excluding the wastewater from the staff facilities and is another point source of groundwater pollution. This type of wastewater is a result of the water used in the industrial processes, which contains various compounds in low or high concentrations, both biological (e.g., wastewater of the food industry, paper industry and textile treatment) and non-biological (wastewater of the chemical industry containing pollutants such as acids, bases, chlorine, metals, cyanide, salts, hydrocarbons, phosphates) [18]. Compared to municipal wastewater, industrial wastewater contains some toxic substances and presents difficulties to effective treatment.

Hospital wastewater represents a major environmental threat and creates serious issues for the natural environment and human health. It is reported that hospital wastewater is 5 to 15 times more toxic than typical urban outflows [19]. The main problems with hospital wastewater are the large daily volumes produced (which is more than five times higher than the typical household production), the content of various microbiological and chemical substances and the fact that this wastewater is often discharged to the sewer network system without 
Table 1. Potential pollution sources of groundwater [18].

\begin{tabular}{|c|c|c|}
\hline Category & Types of contaminants & Source of contamination \\
\hline \multirow{4}{*}{ Residential } & Air pollution & Septic tank \\
\hline & Household waste water & Sewer network \\
\hline & Household waste & Fuel oil \\
\hline & Furniture stripping/refinishing & Paints \\
\hline \multirow{5}{*}{ Municipal } & Municipal sludge spreading in land & Air pollution \\
\hline & Salt for street de-icing & Streets and packing lots \\
\hline & Municipal incinerators & Municipal landfills \\
\hline & Sewer lines & Road maintenance depot \\
\hline & Wastewater treatment plants effluents & \\
\hline \multirow{7}{*}{ Commercial } & Airports & Metal plating \\
\hline & Construction areas & Medical institutions \\
\hline & Car washes & Research laboratories \\
\hline & Cemeteries & Rail road tracks \\
\hline & Dry cleaners & Laundromats \\
\hline & Gas stations & Scap/junk yards \\
\hline & Golf courses & Recycling facilities \\
\hline \multirow{5}{*}{ Industrial } & Chemical industry/storage & Metal fabricators \\
\hline & Electronics manufacture & Petroleum production \\
\hline & Mining and mine drainage & Pipelines \\
\hline & Metal working shops & Storage tanks \\
\hline & Toxic/hazardous spills & Wells \\
\hline \multirow{5}{*}{ Agriculture } & Animal feeds & Fertilizer storage/use \\
\hline & Irrigation sites & Manure spreading areas \\
\hline & Sludge reuse & Chemical spills \\
\hline & Live stocks waste & Pesticides \\
\hline & Tanks & Wells \\
\hline
\end{tabular}

any previous treatment [20] [21] [22]. Potential pollutants and contaminants in hospital wastewater that may result in groundwater pollution are pathogenic microorganisms (including antibiotic resistant bacteria), heavy metals, radioisotopes, organohalogens, pharmaceuticals and drug residues [23].

Landfills are also considered as an important pollution point source of groundwater. Leachates from landfills are rich in nitrogen, chloride, mercury, iron etc. Contamination of aquifers in landfill sites has been detected in many cases around the world over the last decades. Usually, parameters that result in groundwater contamination are bad design or construction of the landfill, inappropriate selection of the installation site or false characterization of the hydro 


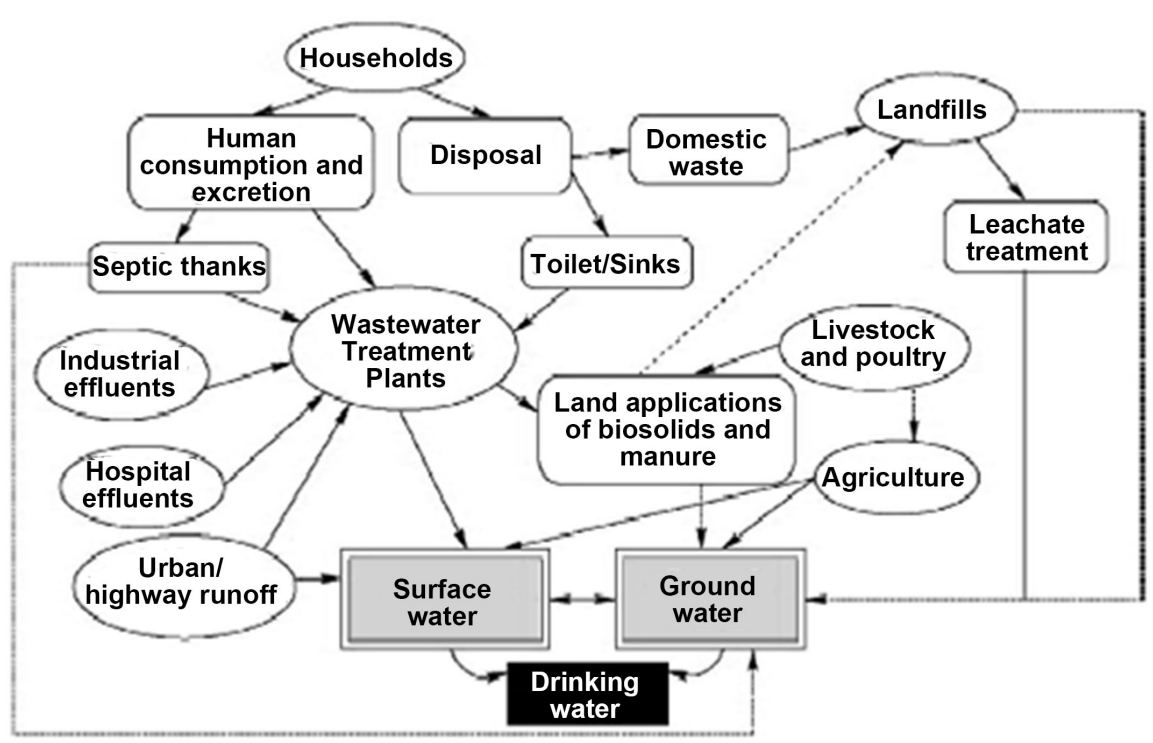

Figure 5. Possible water pollutant sources [17].

geologic regime and soil permeability, among others. Landfill projects usually include groundwater monitoring programs (frequent samplings and analyses, groundwater elevations measurements), while in cases when there are nearby water bodies, monitoring of surface water is also required [24]. Contamination of groundwater with pharmaceutical compounds in landfill sites has been reported in the USA [25], in Croatia [26] and in Denmark [27].

Mining waste are produced during the mining of mineral resources in mines and coal mines, and are a mixture of water and powdered mineral and possibly of heavy metals as by-products [28] [29]. During the excavations, protective soil is removed and thus, the possible pollutants reach the aquifer. Usually, mining activities are extended below the groundwater surface and drainage is necessary. This water is rich in metals and is known as acidic mine water [30]. The excavated area is often used as waste deposit area after the end of mining exploitation, which also results in possible pollution of groundwater. Heavy metal pollution in groundwater due to mining activities poses a threat to human health, especially when groundwater resources are used as drinking water supplies, given that many metals have been identified as potential carcinogenic substances under chronic exposure [30]. Non-point sources are difficult to be identified and they can cover large, extended geographical areas [17].

This type of sources includes natural, chemical infiltration and anthropogenic sources, such as storm water and urban runoff, highway runoff, and agricultural land (use of fertilizers). The use of fertilizers, pesticides, herbicides and animal waste in agriculture is a major non-point source of groundwater contamination [17] [31] [32] [33]. The water which is returned from irrigated areas filtered to the groundwater along with dissolved substances. In this way, elements existing in the fertilizers reach the groundwater, especially in cases of permeable soil formations. Drainage wells are often used by farmers in order to improve the 
drainage of agricultural land and increase its productivity. However, this allows for the direct contamination of groundwater through the washing down of pollutants as agricultural runoff. Common pollutants are nitrates, which have a great mobility and can easily move from the unsaturated zone to the aquifer. In the unsaturated zone the dissolved substances move vertically towards the underground level and in the saturated zone the hydraulic slope causes the horizontal movement of the groundwater and the pollutants. The excessive use of fertilizers results in the increase of nitrate and the respective degradation of the aquifers.

Natural groundwater contamination also falls within the category of non-point sources. The presence of various elements and impurities in groundwater may not be originated from anthropogenic sources. Seawater intrusion is an issue with global dimensions since it contributes to the degradation of coastal freshwater aquifers [34]. Over pumping of groundwater and respective decline in the groundwater level, change in land-use and climate change effect are the main reasons for the incursion of seawater to the coastal groundwater bodies. Seawater intrusion results in a decrease of available freshwater storage volume and the contamination of the production wells in the area, while less than $1 \%$ of seawater is enough to change the water quality to inappropriate for drinking purposes [35]. The type and concentration of the natural elements in groundwater also depend on the nature of the geological materials. Sedimentary rocks and soils usually indicate the presence of various compounds such as magnesium, calcium and chlorides or even chromium in groundwater [36] [37] [38]. Other dissolved constituents such as boron, arsenic and selenium have also been detected in groundwater bodies at relatively high concentrations. All of these elements can be found naturally in soils and rocks and can get dissolved in groundwater. Local conditions regulate the levels of these constituents in groundwater.

\subsection{Impacts/Effects of Pollution}

The impacts/effects of pollution on the Earth include environmental deterioration, impacts on the health of living organisms, global warming, depletion of the ozone layer and reduced efficiency or infertility of farm lands and crop fields. Few of the impacts/effects of pollution are discussed below.

\subsubsection{Health Hazard}

The effect of groundwater pollution on human health can be devastating. It could cause severe sickness which may lead to death in some cases. Such diseases include nausea, vomiting, diarrhea, headache, respiratory diseases, eye irritation and nose irritation. Chronic diseases that could be caused by groundwater pollution include cancer, liver damage, kidney damage, anemia, nervous system problems, circulatory system problems, bone diseases, hair loss and reproductive difficulties. Annual averages of 7 million people were sick in the USA from drinking polluted water [39]. 


\subsubsection{Disruption or Imbalance in the Ecosystem}

Nature has designed the ecosystem to be balanced with one group of organisms depending on the other while over population of a group is controlled by their predators. Any reduction or increase in the population of a group could lead to an imbalance in the ecosystem. Such imbalance may have ripple effect on the whole ecosystem. For example, crocodiles feed on fishes, if all the fishes in a riverine environment die as a result of pollution, this will affect the crocodiles which may lead to them being starved to death or migration.

\subsubsection{Scarcity}

Pollution of groundwater can lead to scarcity of water. A very large percentage of the world's population depends on groundwater for their daily use. When pollution occurs on a large scale, the entire consumers in a community are forced to abandon the consumption of the affected water. Alternative water supply has to be sought. This is always a problem as it is not usually easy to find alternative water supply for a large population.

\subsection{Prevention and Remediation of Groundwater Pollution}

Groundwater pollution threatens the safety usage of water necessitating prevention/remediation where the need arises.

\subsubsection{Prevention of Groundwater Pollution}

Investing in safe drinking water is not only good for personal health and hygiene as well as the environment. It also promotes economic growth. It is therefore necessary to have effective means of preventing groundwater pollution. Prevention of groundwater pollution is the cheapest and most effective solution vis-à-vis remediation [40]. Groundwater pollution can last for years without being detected and by the time it is detected, it must have caused a lot of havoc. Prevention therefore saves tremendous cost. An effective prevention plan should take the following points into consideration: waste disposal, hazardous materials, storm water, management practices, storage tanks and pipelines, small and medium scale business, monitoring wells and water policy formulation.

Wastes should be properly disposed. The disposal plan must ensure proper waste water discharge connections and if possible, floor drains should be eliminated. The plan must provide for proper use and maintenance of on-site septic systems. Plug and cover waste dumpsters must be provided. As for the hazardous materials, chemicals and fuels must be safely stored and handled; underground fuels and chemical tanks should be well monitored. Preference should be given to surface tanks which can be monitored more easily. Storage and loading areas are to be controlled while use of chemicals could be reduced or substituted. Prevention of groundwater from pollution through storm water is to protect chemicals and waste from rain and flood penetrating into the aquifers. Drains could be isolated from storage and loading areas while deicing salt and particles should be sparingly used. It is important to conduct environmental audit periodically. This would lead to the development of pollution prevention plan. 
High risk areas must be regularly inspected while an emergency response plan is developed. Land use plans would need to protect important aquifers and well fields. Residents and businesses must be educated and well informed. Hazardous waste collection must be conducted in all households. All pipelines and storage tanks must be monitored. The right quality of these materials should be procured. Their life span must be noted and they must be replaced at the appropriate time. Those that contain corrosive chemicals should receive special attention. Unused water wells should be properly disposed of. Special attention must be paid to individual, small and medium scale ventures that their activities produce chemical wastes. The level of their financial capability may not enable them to provide adequate preventive measures. The government should come to their aid. Use of insecticides and pesticides should be eliminated or reduced to the barest minimum. This could be done by relying more on waste from livestock. Monitoring wells should be installed at intervals on pipeline network and the vicinity of storage tanks. These would be inspected periodically to ensure early detection of leakages. In addition, the Water Policy formulation should clearly spell out all prevention plans and a body must be tasked to implement the Policy. Awareness measures and penalty should be spelt out and the citizenry should be well informed.

\subsubsection{Remediation of Groundwater Pollution}

Groundwater remediation is the process that can be used to remove pollution from groundwater. Because each groundwater aquifer is unique, mineralization of organic contaminants by either biotic or abiotic mechanisms (e.g., complete conversion of the chemical to $\mathrm{CO}_{2}$ and water) is a function of the spatial heterogeneity of subsurface properties such as pore structure, hydraulic conductivity and microorganism populations as well as carbon and energy sources [41]. This information, along with laboratory studies of degradation, sorption and transport (as described by hydraulic conductivity and chemical dispersion), must be incorporated into plans to design and engineer the proper conditions for restoration in the field. The two approaches described below have some steps in common but differ because bioremediation methods are much more amenable to in-situ operations. If in-situ bioremediation methods can be successfully transferred from the laboratory to the field, they have a clear economic and environmental advantage over physical-chemical methods.

The Physical-chemical methods of aquifer remediation/restoration usually include drilling a well into the contaminant plume to remove contaminated groundwater to the surface. Then a variety of separation methods are available such as air stripping, activated charcoal and reverse osmosis to remove contaminants from groundwater aquifers [42]. After separating contaminants from the aqueous phase, there is still the problem of disposal of toxic organic chemicals, a process usually accomplished by incineration. Recently, studies have been carried out with modified clays that have demonstrated the capacity to absorb pollutant chemicals from groundwater and then act as catalytic surfaces to decompose sorbed chemicals [43]. At the present time, this method has not been 
field tested. In the field, it is proposed to locate a pit upstream from the direction of groundwater flow. The pit would then be loaded with the modified clay and pollutant chemicals would be sorbed onto clay surfaces and degraded.

In the subsurface, biological degradation occurs naturally. However, for some refractory chemicals such as organochlorine pesticides and some organochlorine solvents (e.g., trichloroethylene and tetrachloroethylene), the rates of degradation in many soil environments are slow. Because of this, these chemicals travel great distances from their point of entry without much attenuation in initial entry concentration [44]. Bioremediation of contaminated aquifers include removal of contaminated groundwater to the surface and treatment in a bioreactor and in-situ treatment [3]. Bioreactors located on the surface have the advantage that within these containments bacterial growth can be carefully controlled with appropriate amounts of oxygen and nutrients (nitrogen, phosphorous and carbon sources) can be added to promote rapid decay to high rates of conversion. There are major drawbacks to this method. The high pumping cost for removal of contaminated groundwater from the subsurface makes the capital and operating costs unfavorable. Also, this method cannot remove contaminants sorbed or embedded in the porous media of the subsurface. These residuals represent long term releasing sources of groundwater pollutants. Many laboratory studies have been carried out with microorganisms extracted from contaminated aquifers to determine their ability to degrade a wide variety of organic chemicals [45]. At the present time, there have been only a limited number of studies that have transferred laboratory experiments to field situations. In one study, coal tar chemicals, many of which were polynuclear aromatic hydrocarbons (PAH) were being mineralized in-situ by microorganisms adapted to PAH waste [41]. In another study [40], in biotransformation of chlorinated ethenes, trichloroethylene and tetrachloroethylene was accomplished by stimulating the growth of indigenous methane-oxidizing bacteria (methanotrophs), which transformed these solvents by a co-metabolic process to stable nontoxic end products.

Biotransformation was enhanced by injecting methane and oxygen-containing groundwater in alternating pulses into the zone of contamination in the subsurface. These field experiments have demonstrated that microbial transformations observed in the laboratory can be promoted in-situ in the field when proper conditions are observed.

There are many ways to remove pollution. These methods can be broadly divided into two groups. There are ex-situ and in-situ technologies. Whatever method is employed, groundwater clean-up is a very expensive venture. The cost however depends on extent, potential health effects and the alternatives available. The aquifer may be capped to prevent more pollution. By dewatering the polluted aquifer (pumping out), the water can then be treated on the surface by physical, chemical or biological technology. It is then finally re-injected back into the aquifer. In-situ technology involves treatment of groundwater within the aquifer by using thermal, chemical or biological treatment technology. On the other hand, ex-situ technology may involve the use of the following methods; 
Steam Stripping in which the water is treated by introducing steam which extracts the contaminants from the pumped out groundwater. The extracted steam can be recovered from the condensate or treated further by incineration. Oxygen sparging that involves the introduction of oxidizing and reducing agents. Example includes $\mathrm{O}_{3}, \mathrm{H}_{2} \mathrm{O}_{2}$ and hypochlorite. These will chemically convert the toxic contaminants to less toxic compounds. Bio Remediation which is achieved through treating pumped up groundwater by air with careful control of moisture, heat nutrients, oxygen and $\mathrm{pH}$ and Carbon Adsorption that involves the passing of contaminated pumped up groundwater through activated carbon column in which contaminants get adsorbed.

The in-situ technology involves treatment of groundwater in place without extracting the water from the aquifer. These may come employing Air Sparging. Air Sparging is the injection of contaminant free air into the sub-surface saturated zone which enables a phase transfer of hydrocarbons from a dissolved state to a vapor phase. Other in-situ technology methods are Bio Remediation, In-Well Air Stripping, Chemical Oxidation, Thermal Treatment and Phyto Remediation. Bio Remediation is the injection of oxygen to enhance biodegradation. It also combines the injection of degrading bacteria and nutrients into the aquifer to stimulate biodegradation. In-Well Air Stripping is the injection of air into a double screened well, lifting the water up the well and forcing it out in upper screen. As for the chemical oxidation, it involves reduction-oxidation reactions that chemically convert hazardous contaminants to less toxic compounds. Typical examples of this are cyanide oxidation and dechlorination. Thermal treatment involves increase in temperature of the source zone to increase the mobility of the pollutants. This mobility facilitates removal of pollutants and can also result in in-situ destruction of contaminants. Finally, Phyto remediation involves the use of macroscopic plants to destroy, remove, immobilize and treat contaminants. This process does not use microorganisms.

\section{Conclusion}

Groundwater resources are vital for human life and health, societal development and the preservation of the natural ecosystems. Quality degradation of groundwater bodies as a result of pollution represents a major worldwide issue. Various and multiple sources of groundwater pollution have been identified which include a series of both natural and anthropogenic sources. Human activities such as over abstraction, insufficient wastewater treatment, disposal and industrial activities and use of fertilizers in agriculture represent the main sources of groundwater contaminants. Seawater intrusion is another source of groundwater pollution which results in the salinity increase in coastal groundwater bodies and makes them inappropriate for use as drinking water. Prevention of groundwater from pollution is considered more appropriate to remediation. Prevention methods include proper waste disposal, monitoring of hazardous materials, conducting environmental audit periodically and intensifying health education while remediation measures are stream stripping, oxygen sparging, bioremedia- 
tion, air stripping, chemical oxidation and thermal treatment. This study revealed two main sources of groundwater pollution (point and non-point sources), both of which may be natural or anthropogenic. However, non-point pollution sources are more difficult to remediate due to the extent of spread. In addition, most pollution of groundwater is anthropocentric and can be prevented through intensive health education.

\section{Funding}

This research did not receive any specific grant from funding agencies in the public, commercial, or non-profit sectors.

\section{Conflicts of Interest}

The authors declare no conflicts of interest regarding the publication of this paper.

\section{References}

[1] Humaira, D. and Jose, L.M. (2009) Bridging Divides for Water. 5th World Water (Water Related Migration, Changing Land use and Human settlements, Istanbul, Turkey, 17-18 March 2009). UNW-DPC Publication Series. Knowledge No. 4., 5.

[2] Gleick, P.H. (1996) Water Resources. In: Schneider, S.H., Ed., Encyclopedia of Climate and Weather, Oxford University Press, New York, Vol. 2, 817-823.

[3] World Population Clock (2017) 7.6 Billion People "Worldometer". https://www.worldometers.info

[4] Van Bavel, J. (2013) The World Population Explosion: Causes, Backgrounds and Projections for the Future. Facts, vIews \& Visions in ObGyn, 5, 281-291.

[5] Cosgrove, W.J. and Rijsberman, F.R. (2000) World Water Vision: Making Water Everybody's Business. Earthscan Publishing, London.

[6] Postigo, C., Martinez, D.E., Grondona, S. and Miglioranza, K.S.B. (2018) Groundwater Pollution: Sources, Mechanisms, and Prevention. 87-96.

[7] Currell, M.J. and Han, D. (2017) The Global Drain: Why China's Water Pollution Problems Should Matter to the Rest of the World. Environment. Science and Policy for Sustainable Development, 59, 16-29. https://doi.org/10.1080/00139157.2017.1252605

[8] Kamarudzaman., A.N., Feng, V.K., Aziz, R.A. and Ab Jalil, M.F. (2011) Study of Point and Non Point Sources Pollution-A Case Study of Timah Tasoh Lake in Perlis, Malaysia. 2011 International Conference on Environmental and Computer Science IPCBEE, IACSIT Press, Singapore, Vol. 19.

[9] Konikow, L. and Patten Jr., E. (1985) Groundwater Forecasting. In: Anderson, M.G. and Burt, T.P., Eds., Hydrological Forecasting, John Wiley and Sons Ltd., Chichester.

[10] Canter, L.W., Knox, R.C. and Fairchild, D.M. (1988) Ground Water Quality Protection. Lewis Publishers, Inc., Chelsea, Michigan, 562.

[11] Manson, C.F. (1991) Biology of Freshwater Pollution. 2nd Edition, Longman Scientific and Technical, John Wiley and Sons, Inc., New York, 351.

[12] Connell, D.W. (1981) Water Pollution. University of Queensland Press, Brisbane.

[13] Zaporozec, A. and Miller, J.C. (2000) Groundwater Pollution. UNESCO-PHI, París, 
$1-24$.

[14] Jackson, R.E., Ed. (1980) Aquifer Contamination and Protection. Studies and Reports in Hydrogeology Series, 30. UNESCO, París.

[15] USEPA (1991) "Getting Up to Speed" for Section C, "Ground Water Contamination" Is Adapted from US EPA Seminar Publication. Wellhead Protection: A Guide for Small Communities. Chapter 3. EPA/625/R-93/002.

[16] Pal, A., Gin, K.Y.H., Lin, A.Y.C. and Reinhard, M. (2010) Impacts of Emerging Organic Contaminants on Freshwater Resources: Review of Recent Occurrences, Sources, Fate and Effects. Science of the Total Environment, 408, 6062-6069. https://doi.org/10.1016/j.scitotenv.2010.09.026

[17] Lapworth, D.J., Baran, N., Stuart, M.E. and Ward, R.S. (2012) Emerging Organic Contaminants in Groundwater: A Review of Sources, Fate and Occurrence. Environmental Pollution, 163, 287-303.

[18] Singhal, J.C., Sharma, U.C., Gurjar, B.R. and Gov, J.N. (2014) Environmental Science and Engineering Volume 4 : Water Pollution \& Waste Water Treatment.

[19] Panouillères, M., Boillot, C. and Perrodin, Y. (2007) Study of the Combined Effects of a Paracetic Acid-Based Disinfectant and Surfactants Contained in Hospital Effluents on Daphnia magna. Ecotoxicology, 16, 327-340.

[20] Laber, J., Raimud, H. and Shrestha, R. (1999) Two-Stage Constructed Wetland for Treating Hospital Wastewater in Nepal. Water Science \& Technology, 40, 317-324.

[21] Kümmerer, K. (2001) Drugs in the Environment: Emission of Drugs, Diagnostic Aids and Disinfectants into Wastewater by Hospitals in Relation to Other Sources-A Review. Chemosphere, 45, 957-969. https://doi.org/10.1016/S0045-6535(01)00144-8

[22] Emmanuel, E., Perrodin, Y., Blanchard, J.M., Keck., G. and Vermande, P. (2005) Ecotoxicological Risk Assessment of Hospital Wastewater: A Proposed Framework for Raw Effluents Discharging into Urban Sewer Network. Journal of Hazardous Materials, 117, 1-11. https://doi.org/10.1016/j.jhazmat.2004.08.032

[23] Emmanuel, E., Pierre, M.G. and Perrodin, Y. (2009) Groundwater Contamination by Microbiological and Chemical Substances Released from Hospital Wastewater: Health Risk Assessment for Drinking Water Consumers. Environment International, 35, 718-726. https://doi.org/10.1016/j.envint.2009.01.011

[24] Keister, B.A. and Repetto, P.C. (2007) Landfills. In: Delleur, J.W., Ed., The Handbook of Groundwater Engineering, 2nd Edition, CRC Press, Taylor \& Francis Group, Boca Raton, FL, 33-1-33-31.

[25] Buszka, P.M., Yeskis, D.J., Kolpin, D.W., Furlong, E.T., Zaugg, S.D. and Meyer, M.T. (2009) Waste-Indicator and Pharmaceutical Compounds in Landfill-Leachate-Affected Ground Water near Elkhart, Indiana, 2000-2002. Bulletin of Environmental Contamination and Toxicology, 82, 653-659.

[26] Ahel, M., Mikac, N., Cosovic, B., Prohic, E. and Soukup, V. (1998) The Impact of Contamination from a Municipal Solid Waste Landfill (Zagreb, Croatia) on Underlying Soil. Water Science \& Technology, 37, 203-210.

[27] Holm, J.V., Rügge, K., Bjerg, P.L. and Christensen, H. (1995) Occurrence and Distribution of Pharmaceutical Organic Compounds in the Groundwater down Gradient of a Landfill (Grindsted, Denmark). Environmental Science \& Technology, 29, 1415-1420. https://doi.org/10.1021/es00005a039

[28] Stamatis, G., Voudouris, K. and Karefilakis, F. (2001) Groundwater Pollution by Heavy Metals in Historical Mining Area of Lavrio, Attica, Greece. Water, Air, \& Soil Pollution, 128, 61-83.

[29] Garba, T., Babanyara, Y.Y., Ibrahim, D.B. and Lot, I. (2014) Assessment of Under- 
ground Water Contamination Due to Early Coal Mining Activities in Nigeria. Journal of Environmental Treatment Techniques, 2, 166-170.

[30] Giri, S. and Singh, A.K. (2015) Human Health Risk Assessment via Drinking Water Pathway Due to Metal Contamination in the Groundwater of Subarnarekha River Basin, India. Environmental Monitoring and Assessment, 187, 63-77.

[31] Velthof, G., Oudendag, D., Witzke, H., Asman, W., Klimont, Z. and Oenema, O. (2009) Integrated Assessment of Nitrogen Losses from Agriculture in EU-27 Using MITERRA-EUROPE. Journal of Environmental Quality, 38, 402-417.

[32] Savci, S. (2012) An Agricultural Pollutant: Chemical Fertilizer. International Journal of Environmental Science and Development, 3, 77-80.

https://doi.org/10.7763/IJESD.2012.V3.191

[33] Cruz, J.V., Silva, M.O., Dias, M.I. and Prudencio, M.I. (2013) Groundwater Composition and Pollution Due to Agricultural Practices at Sete Cidades Volcano (Azores, Portugal). Applied Geochemistry, 29, 162-173.

[34] Werner, A.D., Bakker, M., Post, V.E.A., Vandenbohede, A., Lu, C., Ataie-Ashtiani, B., Simmons, C.T. and Barry, D.A. (2013) Seawater Intrusion Processes, Investigation and Management: Recent Advances and Future Challenges. Advances in Water Resources, 51, 3-26.

[35] WHO (2011) Guidelines for Drinking-Water Quality. 4th Edition, IWA Publishing, London, $564 \mathrm{p}$. https://www.who.int/water_sanitation_health/publications/2011/dwq_guidelines/

[36] Megremi, I., Vasilatos, Ch., Atsarou, A., Theodoratou, Ch., Economou-Eliopoulos, M. and Mitsis, I. (2013) Geochemical Evidences for the Sources of the Cr(VI) Contamination in Groundwater in Central Euboea and Assopos-Thiva Basins, Greece: Natural versus Anthropogenic Origin. European Water, 41, 23-34.

[37] Russoniello, C.J., Fernandez, C., Bratton, J.F., Banaszak, J.F., Krantz, D.E., Andres, A.S., Konikow, L.F. and Michael, H.A. (2013) Geologic Effects on Groundwater Salinity and Discharge into an Estuary. Journal of Hydrology, 498, 1-12.

[38] Umar, M., Waseem, A., Sabir, M.A., Kassi, A.M. and Khan, A.S. (2013) The Impact of Geology on Recharge Areas on Groundwater Quality: A Case Study of Zhob River Basin, Pakistan. Clean-Soil, Air, Water, 41, 119-127.

[39] Boulding, J.R. (1995) Practical Handbook of Soil, Vadose Zone and Groundwater Contamination; Assessment, Prevention and Remediation. Leurs Publishers, Boca Raton, FL.

[40] Semprini, L., Roberts, P.V. and Hopkins, G.D. (1990) A Field Evaluation of in-Situ Biodegradation of Chlorinated Ethenes: Part 2, Results of Biostimulation and Biotransformation Experiments. Groundwater, 28, 715-727. https://doi.org/10.1111/j.1745-6584.1990.tb01987.x

[41] Madsen, E.L. (1991) Determining in Situ Biodegradation: Facts and Challenges. Environmental Science \& Technology, 25, 1663-1673. https://doi.org/10.1021/es00022a001

[42] Baier, J.H., Benjamin Jr., W.L., Fronk, C.A. and Kramer, S.J. (1987) Using Reverse Osmosis to Remove Agricultural Chemicals from Groundwater. American Water Works Association, 79, 55-60. https://doi.org/10.1002/j.1551-8833.1987.tb02894.x

[43] Thayer, A.M. (1991) Bioremediation: Innovative Technology for Cleaning Up Hazardous Waste. Chemical Engineering News, 69, 24-44.

[44] Young, C.P. (1983) Technical Guidelines for the Rehabilitation of Groundwater Contaminated by Organochlorine Compounds of Industrial Origin. In: Ziglio, G., Ed., Ground Water Contamination with Organo-chlorine Compounds of Industrial 
Origin, Monduzzi Editore, Bologna, 315-354.

[45] Winter, R.E., Yen, K.M. and Ensley, B.D. (1989) Efficient Degradation of Trichloroethylene by Recombinant Escherichia coli. Biotechnology, 7, 282-285. 